\title{
Neutrophil-lymphocyte ratio in patients with ankylosing spondylitis
}

\author{
Ankilozan spondilit hastalarında nötrofil-lenfosit oranı \\ Mustafa Özşahin ${ }^{1}$, Hilmi Demirin ${ }^{2}$, Taner Uçgun ${ }^{2}$, Fatih Ermiş ${ }^{3}$, Özlem Admış ${ }^{2}$, Safinaz Ataoğlu ${ }^{1}$ \\ ${ }^{1}$ Düzce Üniversitesi Tıp Fakültesi, Fiziksel Tıp Ve Rehabilitasyon Ana Bilim Dalı, Düzce \\ ${ }^{2}$ Düzce Üniversitesi Tıp Fakültesi, Biyokimya Ana Bilim Dalı, Düzce \\ 'Düzce Üniversitesi Tıp Fakültesi, Gastroenteroloji Bilim Dalı, Düzce
}

\section{Özet}

Amaç: Bu çalışmanın amacı, ankilozan spondilit (AS) hastalarındaki inflamasyon ile nötrofil-lenfosit oranı (NLO) arasındaki ilişkiyi belirlemektir.

Yöntem: Ankilozan spondilit tanılı 40 hasta ve 30 sağlıkl gönüllü çalışmaya dahil edildi. Tüm veriler yatan ve poliklinik hasta kayıt veritabanından elde edildi. Tüm olguların Bath Ankilozan Spondilit Hastalık Aktivite Indeksi (BASDAI), tam kan sayımı (TKS), CRP ve ESH'ı da kapsıyan ayrıntılı fizik muayene ve laboratuvar bulguları kaydedildi. Lenfosit ve nötrofil sayısı otomatik TKS'nin bir parças olarak ölçüldü.

Bulgular: Akut-faz reaktanı olan CRP ve ESH kontrol grubuna göre hasta grubunda anlamlı olarak daha yüksekti ( $\mathrm{p}$ 0.05).

Sonuç: Bu çalışmada NLO düzeylerinin AS hastalarında sağlıklı bireylere göre anlamlı olarak yüksek olmadığı görüldü. Bu sonuç NLO'nun AS hastalarında sistemik inflamasyonu değerlendirmede uygun bir ölçü birimi olmadığını götermektedir. Bizim elde ettiğimiz bu ön sonuçların daha ileri çalışmalarla tamamlanması gerektiğine inanıyoruz.

Anahtar Kelimeler: Nötrofil-lenfosit oranı, ankilozan spondilit, enflamasyon, hastalık aktivitesi

\section{Abstract}

Objective: The purpose of the present study is to determine the association between neutrophil-lymphocyte ratio (NLR) and inflammation in ankylosing spondylitis (AS).

Method: Forty patients with ankylosing spondylitis and 30 healthy volunteers were included in the study. All data were obtained from patient registry database from in-patient and out-patient clinics. Detailed physical examination, and Bath Ankylosing Spondylitis Disease Activity Index (BASDAI) were recorded. Complete blood count (CBC), CRP and ESR were performed recorded as laboratory tests in all participants. Lymphocyte and neutrophil counts were measured as part of the automated CBC.

Results: The CRP, which is an acute-phase reactant, and ESR were significantly higher in the patient group than those in the control group (p0.05).

Conclusion: We observed that NLR levels weren't significantly higher in AS patients compared to healthy individuals. NLR hasn't seem a reasonable measure to detect systemic inflammation in AS patients. We believe that our preliminary results need to be complemented with further studies.

Keywords: Neutrophil-lymphocyte ratio, ankylosing spondylitis, inflammation, disease activity.

\section{Introduction}

Ankylosing spondylitis (AS) is a chronic inflammatory rheumatic disease characterized by inflammation in the axial skeleton (spine) with an unknown etiology $(1,2)$. It is an insidious disease, and diagnosis may delay until 5 to 10 years (3). Studies showed several extraarticular manifestations in AS that were thought to be associated with systemic inflammation (e.g. anterior uveitis, subclinical inflammation of the gut, inflammatory bowel disease, psoriasis, cardiac renal lung and bone abnormalities) $(1,2)$.

In AS patients C-reactive protein (CRP) and erythrocyte sedimentation rate (ESR) don't always show the amount of inflammation that is actually present. In AS only $50-70 \%$ of the patients with active disease have elevated level of CRP and a raised ESR (4). Therefore some patients with AS, have normal CRP and ESR levels they may experience a significant amount of inflammation in their bodies. Unfortunately, an optimal test showing the real disease activity and inflammation in AS patients has not yet been developed.

The neutrophile and lymphocyte counts can be obtained from the differential white blood cells count. The neutrophile-lymphocyte ratio (NLR) may be used as indicators of systemic inflammation in various conditions (5). Also it was suggested that NLR has prognostic importance in some diseases $(6,7)$. Among the NLR inflammatory rheumatic diseases, study was made only on familial Mediterranean fever (FMF). It was shown that NLR is associated with inf- 
lammation and amyloidosis in patients with $\operatorname{FMF}(8,9)$. We conducted the present study to investigate the association NLR, CRP, ESR and disease activity in AS patients.

\section{Material and Method}

This is a retrospective clinical study. All data were obtained from patient registry database from in-patient and out-patient clinics. Forty patients ( 26 men and 14 women) who met the modified New York criteria were included in the study (10). The control group consisted of 30 healthy volunteers ( 14 men and 16 women), whom were matched in terms of age and gender.

Patients presenting with acute infection, pneumonia, diabetes mellitus, acute myocardial infarction, coronary artery disease, coronary artery bypass surgery, acute or chronic renal failure, liver disease, malignancy, presence of thalassemia traits, connective tissue disease, inflammatory bowel disease, chronic obstructive pulmonary disease, allergic rhinitis, and asthma were excluded from the study. Baseline demographic and clinical data were obtained and recorded. Detailed physical examination and Bath Ankylosing Spondylitis Disease Activity Index (BASDAI) were also performed. Complete blood count (CBC), CRP and ESR were performed as laboratory tests in all participants. Lymphocyte and neutrophil counts were measured as part of the automated $C B C$ using a CELL-DYN 3700 SL laser hematology analyzer ( Abbott Diagnostics, Chicago, USA).

Analyses were performed by The Statistical Package for Social Sciences software (SPSS 15, Chicago, IL, USA). Descriptive parameters were shown as the mean \pm standard deviation, or in percentages. Kolmogorov Simirnov- $Z$ test was used to analyze the normal distribution of investigated parameters. Continuous variables between groups were compared using the student's $t$ test. Categorical data were compared using the chi-square test. A $P$ value less than 0.05 was considered as significant.

\section{Results}

We studied 40 AS patients and 30 controls (healthy subjects). All of the participants were between the ages of 26 to 56 years. Mean age of the patients with AS and the control group were $39,2 \pm 7,3$ and $35,8 \pm 7,9$ years, respectively. Male/female ratio of patients with AS was $26: 14$, while it was $14: 16$ for the control group. There was no difference between the two groups in terms of age, and gender $(p>0.05)$. Fifteen patients (38\%) were on TNF- $\alpha$ inhibitor treatment arm, 17 patients (42\%) were on sulfasalazine treatment arm, and 8 patients (20\%) were treated by only NSAIDs. Demographic data and clinical characteristics of the study groups are shown in Table 1.

Two groups were evaluated in terms of the NLR values. We found that there was no difference between the two groups in terms of the NLR values ( $p>0.05)$. The CRP, which is an acutephase reactant, and ESR were significantly higher in the patient group than that in the control group $(p<0.05)$. Baseline laboratory characteristics of AS patients and controls were displayed in Table 2. No significant differences were found between NLR and the ages of patients, gender of patients, duration of the illness and treatment, CRP, ESR, and BASDAI ( $p>0.05$ ).

\section{Discussion}

To the best of our knowledge, our study is the first report investigating the NLR in AS patients. Our results demonstrate that NLR levels were not significantly higher in AS patients compared to healthy individuals. Also NLR levels were not correlated with CRP, ESR and BASDAI in AS patients.

Today the NLR is accepted as a parameter showing both neutrophile increase reflecting acute inflammation and also the negative effects caused by lymphocyte decrease reflecting the physiological stress together (11). NLR is considered to be an aid in risk stratification for various cardiovascular diseases in addition to the currently used markers (12-15). Also it was shown that NLR is a prognostic factor for survival in many cancer types (16-18).

While there is no study in literature evaluation the relation between AS and NLR, only 2 studies were made with FMF among the inflammatory rheumatic diseases. Uslu et al. (8) fo- 
und that NLR was significantly higher in patients with FMF compared to healthy individuals. Besides in this study, NLR was found to be significantly higher in patients with FMF related amyloidosis than in patients with amyloidosisfree FMF. According to their evaluation with the cutoff value of NLR $>2.21$, it was a reliable marker in predicting the development of amyloidosis in FMF patients. In the study made by Ahsen et al. (9) NLR levels were significantly higher in FMF patients than those in the control group. Also, there was a positive correlation between CRP and NLR values in patient group. They could not investigate the relationship between NLR and the development of amyloidosis because only two patients had amyloidosis in their participants. Amyloidosis can also be observed in patients with AS and the prevalence is assumed to be $4-5 \%$ (19). As there are no patients with known amyloidosis in our study, NLR and AS related amyloidosis correlation could not be evaluated.

Recent studies have shown that subclinical inflammation continues during the symptomfree period in patients with FMF (20). Similarly, it is known that disease progressively developed in AS patients despite of the treatment (4, 21). Unlike FMF patients NLR levels were not significantly higher in AS patients in our study; this may be explained by intake of antiinflammatory medications. Similarly in another study authors stated that there is a significant relation with NLR in patients having hypertension and diabetes mellitus and that there is not a significant relation with NLR in patients with asthma and arthritis (22). They explained this result as "role of inflammation and NLR might have been masked by the intake of antiinflammatory and pain killer drugs."

Furthermore, in a study showed that NLR is higher in patients with active UC compared with controls and UC patients in remission (23). Also they suggest a cutoff value of 2.47 can be used to identify patients with active UC. It was argued that although the accuracy of the NLR for detecting active UC is suboptimal, assist in identifying patients at increased risk of active and severe disease. Ulcerative colitis (UC) is a chronic inflammatory bowel disease that can cause sacroiliitis like AS. It was also shown that in $30-60 \%$ of the AS diseases, there were subclinical intestinal inflammation (24). However in our study NLR levels were not correlated with $\mathrm{CRP}, \mathrm{ESR}$ and disease activity.

Among the limitations of our study are it's retrospective design and representation of only a single-center experience. The study has a relatively small sample size, and the results we obtained need to be confirmed further in a larger group of patients.

Despite the limitations of the study, we observed that NLR levels weren't significantly higher in AS patients compared to healthy individuals. And NLR hasn't seem a reasonable measure to detect systemic inflammation in AS patients. We believe that our preliminary results need to be complemented with further studies.

\section{References}

1. Khan MA. Update on spondyloarthropathies. Ann Intern Med 2002; 136: 896-907.

2. Elewaut $D$, Matucci-Cerinic M. Treatment of ankylosing spondylitis and extra-articular manifestations in everyday rheumatology practice. Rheumatology (Oxford) 2009; 48: 1029-35.

3. Calin A, Brophy S, Blake D. Impact of sex on inheritance of ankylosing spondylitis: a cohort study. Lancet 1999; 354: 1687-90.

4. Ozgocmen S, Godekmerdan A, Ozkurt-Zengin F. Acute-phase response, clinical measures and disease activity in ankylosing spondylitis. Joint Bone Spine 2007; 74: 249-53.

5. Zahorec R. Ratio of neutrophil to lymphocyte counts--rapid and simple parameter of systemic inflammation and stress in critically ill. Bratisl Lek Listy 2001; 102: 5-14.

6. Tasoglu I, Sert D, Colak N, Uzun A, Songur M, Ecevit A. Neutrophil-Lymphocyte Ratio and the Platelet-Lymphocyte Ratio Predict the Limb Survival in Critical Limb Ischemia. Clin Appl Thromb Hemost 2013 Feb 6. [Epub ahead of print]

7. Biyik $M$, Ucar R, Solak $Y$, Gungor G, Polat I, Gaipov A, Cakir OO, Ataseven H, Demir A, Turk $\mathrm{S}$, Polat H. Blood neutrophil-to-lymphocyte ratio independently predicts survival in patients with liver cirrhosis. Eur J Gastroenterol Hepatol 2013; 25: 435-41. 
8. Uslu AU, Deveci K, Korkmaz S, Aydin B, Senel $S$, Sancakdar E, Sencan M. Is neutrophil/lymphocyte ratio associated with subclinical inflammation and amyloidosis in patients with familial Mediterranean fever? Biomed Res Int 2013; 2013: 185317. Epub 2013 Jun 20.

9. Ahsen A, Ulu MS, Yuksel S, Demir K, Uysal M, Erdogan M, Acarturk G. As a New Inflammatory Marker for Familial Mediterranean Fever: Neutrophil-to-Lymphocyte Ratio. Inflammation 2013 Jun 21. [Epub ahead of print]

10. van der Linden S, Valkenburg HA, Cats A. Evaluation of diagnostic criteria for ankylosing spondylitis. A proposal for modification of the New York criteria. Arthritis Rheum 1984; 27: 361-8.

11. Gibson PH, Cuthbertson BH, Croal BL, Rae D, El-Shafei H, Gibson G, Jeffrey RR, Buchan KG, Hillis GS. Usefulness of neutrophil/lymphocyte ratio as predictor of new-onset atrial fibrillation after coronary artery bypass grafting. Am J Cardiol 2010; 105: 186-91.

12. Bhat T, Teli S, Rijal J, Bhat H, Raza M, Khoueiry $\mathrm{G}$, Meghani M, Akhtar M, Costantino T. Neutrophil to lymphocyte ratio and cardiovascular diseases: a review. Expert Rev Cardiovasc Ther 2013; 11: 55-9.

13. Oztürk $S$, Erdem A, Ozlü MF, Ayhan $S$, Erdem K, Ozyaşar M, Aslantaş Y, Yazıcı M. Assessment of the neutrophil to lymphocyte ratio in young patients with acute coronary syndromes. Turk Kardiyol Dern Ars 2013; 41: 284-9.

14. Gazi E, Bayram B, Gazi S, Temiz A, Kirilmaz B, Altun B, Barutcu A. Prognostic Value of the Neutrophil-Lymphocyte Ratio in Patients With ST-Elevated Acute Myocardial Infarction. Clin Appl Thromb Hemost 2013 Jun 9. [Epub ahead of print]

15. Ayhan SS, Oztürk S, Erdem A, Ozlü MF, Ozyaşar M, Erdem K, Yazıcı M. Relation of neutrophil/lymphocyte ratio with the presence and severity of coronary artery ectasia. Turk Kardiyol Dern Ars 2013; 41: 185-90.

16. Shibutani M, Maeda K, Nagahara H, Noda E, Ohtani $\mathrm{H}$, Nishiguchi $\mathrm{Y}$, Hirakawa K. A high preoperative neutrophil-to-lymphocyte ratio is associated with poor survival in patients with colorectal cancer. Anticancer Res 2013; 33: 3291-4.

17. de Martino M, Pantuck AJ, Hofbauer S, Waldert M, Shariat SF, Belldegrun AS, Klatte T. Prognostic Impact of Preoperative NeutrophilTo-Lymphocyte Ratio in Localized Nonclear Cell Renal Cell Carcinoma. J Urol 2013 Jul 2. [Epub ahead of print]

18. Stotz M, Gerger A, Eisner F, Szkandera J, Loibner H, L Ress A, Kornprat P, A Zoughbi W, Seggewies FS, Lackner C, Stojakovic T, Samonigg $\mathrm{H}$, Hoefler $\mathrm{G}$, Pichler $\mathrm{M}$. Increased neutrophil-lymphocyte ratio is a poor prognostic factor in patients with primary operable and inoperable pancreatic cancer. Br J Cancer 2013; 109: 416-21. Epub 2013 Jun 25.

19. Dhillon V, Woo P, Isenberg D. Amyloidosis in the rheumatic diseases. Ann Rheum Dis 1989; 48: 696-701.

20. Lachmann HJ, Sengül B, Yavuzşen TU, Booth DR, Booth SE, Bybee A, Gallimore JR, Soytürk M, Akar S, Tunca M, Hawkins PN. Clinical and subclinical inflammation in patients with familial Mediterranean fever and in heterozygous carriers of MEFV mutations. Rheumatology (Oxford) 2006; 45: 746-50.

21. Her M, Kavanaugh A. Treatment of spondyloarthropathy: the potential for agents other than TNF inhibitors. Curr Opin Rheumatol 2013; 25: 455-9.

22. Imtiaz F, Shafique K, Mirza SS, Ayoob Z, Vart $P$, Rao $S$. Neutrophil lymphocyte ratio as a measure of systemic inflammation in prevalent chronic diseases in Asian population. Int Arch Med 2012; 5: 2.

23. Celikbilek M, Dogan S, Ozbakır O, Zararsız G, Kücük H, Gürsoy S, Yurci A, Güven K, Yücesoy $M$. Neutrophil-lymphocyte ratio as a predictor of disease severity in ulcerative colitis. J Clin Lab Anal 2013; 27: 72-6.

24. Mielants H, De Keyser F, Baeten D, Van den Bosch F. Gut inflammation in the spondyloarthropathies. Curr Rheumatol Rep 2005; 7: 18894. 
Table 1: Demographic data on, and clinical characteristics of, our study group.

\begin{tabular}{|c|c|c|c|}
\hline Variable & AS Group ( $n=40)$ & Control Group (n=30) & P Value \\
\hline Mean age (years) & $39,2 \pm 7,3$ & $35,8 \pm 7,9$ & 0.067 \\
\hline Gender/male, n (\%) & $26(65)$ & $14(47)$ & 0.125 \\
\hline Disease duration (years) & $6,24 \pm 5,96$ & - & - \\
\hline BASDAI & $3,98 \pm 2,28$ & - & - \\
\hline \multicolumn{4}{|l|}{ Treatment } \\
\hline NSAID, n (\%) & & - & - \\
\hline Sulfasalazin, n (\%) & & - & - \\
\hline Anti TNF agents, $\mathrm{n}(\%)$ & & - & - \\
\hline
\end{tabular}

Values are means \pm SD or numbers and percentages. BASDAI: Bath Ankylosing Spondylitis Disease Activity, NSAID: Nonsteroidal Anti-Inflammatory Drugs, TNF: Tumor Necrosis Factor.

Table 2: Baseline laboratory characteristics of our study group.

\begin{tabular}{|c|c|c|c|}
\hline Variable & AS Group $(n=40)$ & Control Group $(n=30)$ & P Value \\
\hline WBC & $6,64 \pm 1,1$ & $6,63 \pm 2,16$ & 0.983 \\
\hline Neutrophil, $\times 10^{9} / \mathrm{L}$ & $3,79 \pm 0,95$ & $3,86 \pm 1,73$ & 0.842 \\
\hline Lymphocyte, $\times 10^{9} / \mathrm{L}$ & $2,19 \pm 0,51$ & $2,14 \pm 0,63$ & 0.73 \\
\hline NLR & $1,84 \pm 0,64$ & $1,84 \pm 0,7$ & 0.959 \\
\hline $\mathrm{ESR}, \mathrm{mm} / \mathrm{h}$ & $13,13 \pm 10,89$ & $8,68 \pm 5,84$ & 0.038 \\
\hline CRP, mg/L & $0,66 \pm 0,83$ & $0,28 \pm 0,42$ & 0.017 \\
\hline
\end{tabular}

Values are means \pm SD or numbers and percentages. WBC: White blood cell, NLR: Neutrophil-lymphocyte ratio ESR: Erythrocyte sedimentation rate, CRP: C-reactive protein 